\title{
PENGARUH MODEL PEMBELAJARAN TWO STAY - TWO STRAY TERHADAP HASIL BELAJAR SISWA PADA MATA PELAJARAN EKONOMI DISMA MUHAMMADIYAH 1 PALEMBANG
}

\author{
Oleh : Remi Aliarti \\ (SMA NEGERI 1 SEKAYU) \\ remialiarti970@gmail.com
}

\begin{abstract}
Abstrak-Masalah dalam penelitian ini yaitu apakah ada pengaruh model pembelajaran two stay two stray terhadap hasil belajar siswa pada mata pelajaran ekonomi di SMA Muhammadiyah 1 Palembang. Metode penelitian yang dipergunakan dalam penelitian ini adalah metode eksperimen. Teknik penggumpulan data yang digunakan adalah observasi, dokumentasi, dan tes Populasi dalam penelitian ini adalah seluruh kelas X IPS yang berjumlah 121 siswa. Sampel dalam penelitian ini sebanyak 58 siswa. Hasil penelitian menunjukkan bahwa nilai rata-rata hasil belajar kelas kelas eksperimen yaitu 84,59\%, sedangkan nilai rata-rata hasil belajar kelas kontrol yaitu 63,66\%. Hasil analisis data menunjukkan terdapat pengaruh signifikan antara model pembelajaran two stay two stray terhadap hasil belajar siswa. Besarnya pengaruh antara model pembelajaran two stay two stray terhadap hasil belajar siswa adalah 79,48 \% sedangka sisanya sebesar 20,52 \% dipengaruhi faktor lain.
\end{abstract}

Kata Kunci : Model Pembelajaran Two Stay Two Stray, Hasil Belajar

\begin{abstract}
The problem in this research is whether there is an influence of the two stay two stray learning model on student learning outcomes in economic subjects at Muhammadiyah 1 High School Palembang. The research method used in this study is the experimental method. Data collection techniques used were observation, documentation, and tests The population in this study were all $X$ social studies classes totaling 121 students. The sample in this study were 58 students. The results showed that the average value of learning outcomes of the experimental class class was $84.59 \%$, while the average value of learning outcomes of the control class was $63.66 \%$. The results of data analysis showed that there was a significant influence between the two stay two stray learning models on student learning outcomes. The amount of influence between the two stay two stray learning models on student learning outcomes is $79.48 \%$ while the remaining $20.52 \%$ is influenced by other factors.
\end{abstract}

Keywords: Learning Model, Beach Ball Type Class Discussion, Learning Outcomes. 


\section{PENDAHULUAN}

Pendidikan merupakan sesuatu yang senantiasa menarik untuk dipelajari, dipahami dan untuk mencari solusi, karena pendidikan memiliki peran yang sangat penting terhadap setiap individu itu sendiri. Pendidikan juga sangatlah penting bagi kehidupan manusia, karena dari pendidikan manusia akan mengetahui tentang apa-apa saja disekelilingnya baik nama, kegunaan dan manfaatnya. Didalam suatu proses belajar mengajar, guru harus mempunyai strategi atau cara-cara khusus agar siswa dapat belajar secara efektif dan efisien serta sesuai dengan tujuan yang diharapkan. Salah satu langkah untuk mempunyai strategi itu ialah harus menguasai gaya-gaya penyajian atau bisa kita sebut juga dengan model pembelajaran.

Pendidikan yang memadai tentu memiliki peran yang sangat penting dalam ilmu pengetahuan.Memadai disini artinya kebutuhan pendidikan yang terpenuhi baik segi sarana maupun prasarana. Di dalam proses belajar mengajar guru tentu memiliki peran yang sangat penting dalam menentukan kualitas dari pembelajaran yang dilaksanakan, guru juga harus memikirkan, merencanakan, menyusun konsep secara maksimal dan melakukan evaluasi terhadap pembelajaran yang dilakukan serta meningkatkan hasil belajar siswa. Salah satu yang dimiliki peran yang sangat penting bagi keberhasilan pengajaran ialah proses pelaksanaan pembelajaran. Proses pelaksanaan pembelajaran yang baik adalah pembentukan perencanaan yang kritis dan menyusun suatu konsep secara maksimal. Hal ini harus dilakukan ketika selesai melakukan proses pembelajaran adalah mengevaluasi dengan melihat hasil siswa melalui nilai dari soal yang diberikan

Model pembelajaran merupakan strategi yang digunakan guru dalam menyampaikan materi. Model pembelajaran pada dasarnya merupakan bentuk pembelajaran yang tergambar dari awal sampai akhir yang disajikan secara khas oleh guru. dengan kata lain,model pembelajaran merupakan bungkus atau bingkai dari penerapan suatu pendekatan (Komalasari,2011:57). Alasan peneliti memilih model pembelajaran adalah :

a) Dengan melaksanakan model pembelajaran siswa memungkinkan dapat meraih keberhasilan dalam belajar.

b) Di samping itu juga bias lebih melatih siswa untuk memilih keterampilan,yaitu keterampilan berpikir (thinking skill).

c) Dan mengurangi timbulnya perilaku yang menyimpan dalam kehidupan kelas.

Model pembelajaran merupakan sebuah rencana atau pola yang mengorganisasi pembelajaran dalam kelas dan menunjukkan cara 
penggunaan materi pembelajaran. Model pembelajaran adalah cara-cara atau teknik penyajian bahan ajaran yang akan digunakan oleh guru pada saat menyajikan bahan pelajaran, baik secara individual maupun secara kelompok. Model pembelajaran dapat dijadikan pola pilihan, artinya para guru boleh memilih model pembelajaran yang sesuai dan efisien untuk mencapai tujuan pendidikan.Tujuan pembelajaran dapat dicapai dengan optimal diperlukan berbagai model pembelajaran.

Untuk membantu strategi pembelajaran yang aktif ini, guru dapat menerapkan berbagai metode pembelajaran dan model pembelajaran yang relevan.Salah satu model yang di terapkan dalam pembelajaran yang relevan adalah model pembelajaranTwo Stay-Two Stray.Menurut Ngalimun (2018: 238) Model Pembelajaran TS-TS (Two Stay-Two Stray) adalah dengan cara siswa berbagi pengetahuan dengan kelompok lain.singkatnya adalah kerja kelompok, dua siswa bertemu kekelompok lain dan dua siswa lainnya tetap dikelompoknya untuk menerima dua orang dari kelompok lain,kerja kelompok, kembali kekelompok asal,kerja kelompok, laporan kelempok.

Ciri-ciri model pembelajaran Two Stay-Two Stray yaitu siswa berkerja berkolompok untuk menuntaskan materi belajarnya. Kelompok dibentuk dari siswa yang memiliki kemampuan tinggi, sedang dan rendah, penghargaan lebih berorientasi pada kelompok daripada individu. Adapun kelebihan dan kekurangan model pembelajan TSTS. Kelebihannya dapat diterapkan pada semua kelas atau tindakan, kecenderungan belajar siswa menjadi lebih bermakna, lebih berorientasi pada keaktifan, diharapkan siswa akan berani mengungkapkan pendapatnya, kemampuan berbicara siswa dapat ditingkatkan dan membantu meningkatkan minat dan proses belajar. Sedangkan kekurangannya adalah membutuhkan waktu yang lama, siswa cenderung tidak mampu belajar dalam kelompok, karena tidak terbiasa sehingga merasa asing dan sulit untuk bekerja sama dan siswa yang pandai menguasai jalannya diskusi, sehingga siswa yang kurang pandai lebih sedikit dalam mempunyai kesemptan untuk mengeluarkan pendapatnya.

Hasil observasi yang saya lakukan di sekolah dengan salah satu guru mata pelajaran ekonomi di SMA Muhammadiyah 1 Palembang yang bernama ibu Ferlina Sarimengatakan bahwa masih banyak siswa yang mengalami kesulitan dalam memahami materi pelajaran ekonomi yang diberikan oleh guru hal ini disebabkan karena dalam menyampaikan materi, guru masih menggunakan metode yang belum bervariasi sehingga monoton pada siswa sehingga membosankan 
untuk mengikuti proses pembelajaran. Dengan demikian siswa menjadi kurang aktif dalam menerima materi yang disampaikan oleh guru pada akhirnya berpengaruh terhadap hasil belajar siswa. Sehingga untuk menerapkan model pembelajaraan two stay - two stray agar meningkatkan minat belajar siswa terhadap pelajaran ekonomi melalui media gambar dalam menyampai materi dan siswa tidak bosan dalam belajar.

Bertitk tolak dari permasalahan diatas,maka peneliti tertarik untuk melakukan penelitian yang berjudul'Pengaruh Model Pembelajaran Two Stay -Two Stray Terhadap hasil Belajar Siswa Pada Mata Pelajaran Ekonomi Kelas X diSMA Muhammadiyah 1 Palembang Tahun Pelajaran 2019/2020".

Pembelajaran pada dasarnya informasi awal untuk membantu peserta didik dalam melakukan kegiatan belajar, pengembangan dan penemuan informasi baru sehingga pada saat penyampaian informasi, yang dihasilkan adalah pengertian yang jelas, pembelajaran juga salah satu yang bertujuan untuk membantu proses belajar mengajar yang berisi informasi, seperti serangkaian peristiwa yang disusun sedemikian rupa untuk mendukung dan mempengaruhi terjadinya proses belajar siswa yang efektif.

Menurut Putra (2013:15) Pembelajaran merupakan aktivitas yang paling utama. Ini berarti bahwa keberhasilan pencapaian tujuan pendidikan banyak bergantung pada bagaimana proses pembelajaran dapat berlangsung secara efektif

Menurut Huda, (2013:02) Pembelajaran dapat dikatakan sebagai hasil dari memori, kognisi, dan metakognisi yang berpengaruh terhadap pemahaman. Hal inilah yang terjadi ketika seseorang sedang belajar, dan kondisi ini juga sering terjadi dalam kehidupan sehari-hari, karena belajar merupakan proses alamiah setiap orang.

Menurut Suprijono (2009:46) Pembelajaran ialah pola yang digunakan sebagai pedoman dalam merencanakan pembelajaran dikelas maupun tutorial.

Menurut Ngalimun (2017:37) Model Pembelajaran adalah suatu perencanaan atau suatu pola yang digunakan sebagai pedoman dalam merencanakan pembelajaran dikelas.

Menurut

Rosdiani (2012:5)menyatakan bahwa "Model Pembelajaran merupakan sebuah rencana yang dimanfaatkan untuk merancang.isi yang terkandung didalam model pembelajaran adalah berupa strategi pengajaran yang digunakan untuk mencapai tujuan instruksional."

Menurut Rusman (2016 :133) menyatakan bahwa "Model Pembelajaran adalah suatu rencana atau pola yang dapat digunakan untuk membentuk kurikulum (rencana pembelajaran jangka 
panjang,merancang bahan-bahan pembelajaran,dan membimbing pembelajaran dikelas atau yang lain."

Menurut Serly Wanti (2011:7) Model Pembelajaran adalah suatu perencanaan atau suatu pola yang digunakan sebagai pedoman dalam merencanakan pembelajaran di kelas atau pembelajaran dalam tutorial untuk menentukan perangkatperangkat pembelajaran termasuk didalamnya buku-buku, film,komputer,kurikulum dan lainlain.

\begin{tabular}{lrr}
\multicolumn{1}{c}{ Fungsi } & Model & Pembelajaran \\
adalah & sebagai & pedoman \\
perancangan & dalam & pelaksanaan \\
pembelajaran. & &
\end{tabular}

Menurut Huda (2011:140) Model Pembelajaran Dua Tinggal Dua Tamu (Two Stay-Two Stray) dikembangkan oleh Spancer Kagan (1990).Dapat dikombonisikan dengan teknik kepala bernomor ,dapat diterapkan untuk semua mata pelajaran dan tingkat umur, memungkinkan setiap kelompok untuk saling berbagi informasi dengan kelompok kelompok lain".

Menurut Fovi Riana Samroni (2013:02)Model Pembelajaran TwoStay -Two Stray ini, siswa dibagi menjadi beberapa kelompok hetogen,masing-masing 4 siswa. Mereka berdiskusi atau bekerja sama membuat laporan suatu peristiwa mengenai materi Konsep Dasar Ilmu Ekonomi.

Belajar merupakan komponen ilmu pendidikan yang berkenaan dengan tujuan dan bahan acuan interaksi, baik yang bersifat eksplisit maupun implicit (tersembunyi)

Menurut Sagala belajar merupakan ilmu pendidikan yang berkenaan dengan tujuan dan bahan acuan interaksi, baik yang bersifat eksplisit maupun implisit (tersembunyi).

Menurut Jihad \& Haris (2013:1) belajar adalah kegiatan berproses dan merupakan unsur yang sangat fundamental dalam penyelenggaraan jenis dan jenjang pendidikan, hal ini berarti keberhasilan pencapaian tujuan pendidikan sangat tergantung pada keberhasilan proses belajar siswa di sekolah dan lingkungan sekitarnya.

Menurut Fathurrohman \& Sutikno (2010:6) belajar pada hakikatnya adalah "perubahan" yang terjadi di dalam diri seseorang setelah melakukan aktivitas tertentu.Walaupun kenyataanya tidak semua perubahan termasuk kategori belajar. Misalnya fisik, mabuk, gila, dan sebagainya.

Suprijiono

(2009:7)

mengatakan bahwa "Hasil belajar adalah perubahan perilaku secara keseluruhan bukan hanya satu aspek potensi kemanusiaan saja artinya ,hasil pembelajaran yang dikategoriskan oleh para pakar sebagaimana tersebut diatas tidak dilihat secara fragmentaris atau terpisah melainkan komprehensif'.

Suprijono (2009:5)

mengatakan bahwa "Hasil Belajar 
adalah pola - pola perbuatan,nilai nilai ,pegertian-pengertian, sikapsikap apresiasi dan juga keterampilan".

Menurut Fovi Riana Samroni (2013:14) Hasil Belajar merupakan perubahan perilaku yang diperoleh setelah mengalami aktivitas belajar.perubahan perilaku tersebut seperti keterampilan, pengetahuan, pemahaman, sikap, nilai yang diperoleh siswa dari proses belajar mengajar.

Ilmu ekonomi atau ekonomi politik (political economy), adalah suatu studi tentang kegiatan-kegiatan yang dengan atau tanpa menggunakan uang, mencakup atau melibatkan transaksi-transaksi pertukaran antarmanusia Rosyidi (2011:8).Selain itu Menurut Rosyidi (2011:9) ilmu ekonomi adalah studi mengenai cara-cara yang ditempuh oleh masyarakat untuk menggunakan sumber daya yang langka guna memproduksi komoditas atau barang-barang yang bermanfaat serta mendistribusikannya kepada semua orang. Sedangkan, menurut Alam \&Rudianto (2014:35) Ekonomi adalah salah satu bidang pengkajian yang mencoba menyelesaikan masalah keperluan asas kehidupan manusia melalui pengembangan segala sumber ekonomi yang ada dengan berasaskan prinsip serta teori tertentu dalam suatu sistem ekonomi yang dianggap efektif dan efisien.

\section{METODOLOGI PENELITIAN}

Metode penelitian yang dipergunakan dalam penelitian ini adalah metode eksperimen. Metode eksperimen dapat diartikan sebagai metode penelitian yang digunakan untuk mencari penegaruh perlakuan tertentu terhadap yang lain dalam kondisi yang terkendali (Sugiono,2012:17).

Metode Eksperimen Mempunyai Kelebihan Dan Kekurangan:

Kelebihan Metode Eksperimen yaitu

1. Membuat siswa lebih percaya atas kebenaran atau kesimpulan berdasarkan percobaannya.

2. Dapat membina siswa untuk membuat terobosan-terobosan baru dengan penemuan dari hasil percobaannya dan bermanfaat bagi kehidupan manusia.

3. Hasil-Hasil percobaan yang berharga dapat dimanfaatkan untuk kemamkuran umat manusia.

Kekurangan

Metode

Eksperimen yaitu:

1. Metode ini lebih sesuai dengan bidang-bidang sain dan teknologi.

2. Metode ini memerlukan berbagai fasilitas peralatan dan bahan yang tidak selalu mudah diperoleh dan mahal.

3. Metode ini menuntut ketelitian, keuletan,dan ketabahan.

4. Setiap percobaan tidak selalu hasil yang diharapkan karena mungkin ada factor-faktor tertentu yang berada diluar jangkauan 
kemampuan atau pengendalian.

Menurut Syaibul bahri dkk (2010:84).

Berdasarkan desain diatas,maka untuk siswa kelas eksperimen $\left(\mathrm{R}_{1}\right)$ yang mendapatkan perlakuan dengan menggunakan meodel pembelajaran Two Stay Two Stray (X) sedangkan untuk kelas kontrol $\left(\mathrm{R}_{2}\right)$ tanpa menggunkan model pembelajaran

Two Stay Two Stray namun menggunakan metode konvensional .Kemudian setelah proses pembelajaran dibeikan perlakuan diberikantes baik kelas eksperimen maupun kelas control $\left(\mathrm{O}_{1}\right.$ dan $\left.\mathrm{O}_{2}\right) \mathrm{Hal}$ ini bertujuan untuk mengetahui hasil belajar pada mata pelajaran ekonomi.

\section{Teknik Pengumpulan Data}

Pengumpulan data menggunakan beberapa teknik dalam pengumpulan data yang diperlukan ,yaitu sebagai berikut:

\section{Observasi}

Menurut Sugiono (2014:228)

Observasi merupakan proses pengamatan dan pencacatan secara sistematis mengenai gejala-gejala yang diteliti dan diamati.dapat dikatakan juga bahwa observasi adalah salah satu metode pengumpulan data dengan mengamati atau meninjau secara cemat dan langsung dilokasi penelitian atau lapangan untuk mengetahui secara langsung kondisi yang terjadi atau untuk membuktikan kebenaran dari sebuah desain penelitian.

\section{Dokumentasi}

Menurut Sugiono (2016:240) Dokumentasi merupakan catatan peristiwa yang sudah berlalu.Dokumentasi bisa berbentuk tulisan, yang berupa misalnya catatan harian, sejarah kehidupan (life histirical), biografi, peraturan, kebijakan. Dokumentasi yang berbentuk gambar, misalnya foto, gambar kehidupan, sketsa,dan lainlain.

Tes

Tes adalah serangkaian pertanyaan atau latihan yang digunakan untuk mengukur keterampilan, pengetahuan, intelegensi, kemampuan, atau bakat yang dimiliki oleh individu atau kelompok (Arikunto, 2013:266). Teknik tes dalam penelitian ini digunakan untuk memperoleh data hasil belajar siswa pada mata pelajaran ekonomi. Tes disajikan dan dijawab dalam bentuk Pilihan Ganda setelah proses belajar mengajar selesai. Soal Tes berisi 30 soal pilihan ganda dengan menggunakan materi "Konsep Dasar Ilmu Ekonomi”.

\section{HASIL DAN PEMBAHASAN}

Berdasarkan hasil analisis di atas, pengaruh hasil belajar tersebut dikarenakan dalam pelaksanaan 
proses pembelajaran pada kelas eksperimen yang diterapkan model pembelajaran two stay two stray siswa diusahakan aktif dalam proses pembelajaarnnya. Kesan yang dialami oleh siswa lebih mendalam dan tertanam dalam ingatan yang pada akhirnya berdampak pada peningkatan siswa tersebut dalam penguasaan materi yang diberikan. Sedangkan dalam pelaksanaanya proses pembelajaran yang dilakukan, hal ini pun berdampak pada siswa mengenai penguasaan materi yang diberikan.

Hal tersebut dikarenkan pada model pembelajaran model pembelajaran two stay two stray siswa berperan aktif dalam pembelajaran, baik dalam menentukan topik permasalahan maupun cara untuk menyelesaikannya. Kesuksesan model pembelajaran model pembelajaran two stay two stray juga terbukti pada penelitian ini, ternyata dengan penerapan model pembelajaran model pembelajaran two stay two stray siswa dapat lebih aktif dalam proses pembelajaran dan berpengaruh terhadap kesungguhan siswa dalam proses belajar mengajar. Hal ini terlihat rata-rata hasil belajar yang diperoleh siswa melalui tes.

Model pembelajaran adalah kerangka konseptual yang menggambarkanprosedursistematika dalam

mengorganisasikanpengalaman

belajar untuk mencapai tujuan belajar. Sedangkan Model Pembelajaran Two Stay-Two Straymerupakan sistem pembelajaran kelompok dengan tujuan agar siswa dapat saling bekerja sama, bertanggung jawab, saling membantu memecahkan masalah, dan saling mendorong satu sama lain untuk berprestai.

Model pembelajaran two stay two stray baik diterapkan pada materi konsep dasar ilmu ekonomi, karena materi tersebut memberikan kesempatan bagi siswa untuk lebih aktif berdiskusi, mencari informasi dari pengalaman atau kejadian sehari-hari. Sedangkan metode ceramah siswa hanya mendengarkan penjelasan peneliti kemudian mengerjakan tugas yang diberikan oleh peneliti.

Berdasarkan hasil distribusi belajar kelas eksperimen yang memperoleh nilai pada kriteria "Baik Sekali” sebesar $55,17 \%$, yang memperoleh nilai pada kriteria "Baik" sebesar 34,48\%, yang memperoleh nilai pada kriteria "Cukup" sebesar 10,34\% dan tidak ada yang memperoleh nilai pada kriteria "Kurang" dan "Kurang Sekali”. Rata-rata nilai hasil belajar siswa pada kelas eksperimen adalah sebesar 84,59\%. Sedangkan hasil distribusi belajar kelas kontrol yang memperoleh nilai pada kriteria "Baik" sebesar 6,896\%, yang memperoleh nilai pada kriteria "Cukup" sebesar 79,31\%, yang memperoleh nilai pada kriteria 
"Kurang" sebesar 10,34\%, yang memperoleh nilai pada kriteria "Kurang Sekali" sebesar 3,448\% dan tidak ada yang memperoleh nilai pada kriteria "Baik Sekali". Rata-rata nilai hasil belajar siswa pada kelas kontrol adalah sebesar 63,66\%. Berdasarkan penelitian yang dilakukan peneliti diperoleh nilai $\mathrm{t}_{\text {hitung }}=8,949>$ dari $\mathrm{t}_{\text {tabel }}=1,994$ berarti tolak Ho dan terima $\mathrm{H} \alpha$ maka hipotesis penelitian berbunyi ada pengaruh yang signifikan model pembelajaran two stay two stray terhadap hasil belajar siswa di SMA Muhammadiyah 1 Palembang.

\section{KESIMPULAN DAN SARAN}

Berdasarkan hasil analisis data mengenai pengaruh model pembelajan Two Stay Two Stray terhadap hasil belajar siswa pada mata pelajaran ekonomi di SMA Muhammadiyah 1 Palembang disimpulkan sebagai berikut:

1. Berdasarkan hasil hipotesis yang dilakukan menggunakan uji $\mathrm{t}$ adapun rumus regresi yang digunakan adalah regresi linear sederhana, terdapat pengaruh model pembelajaran Two Stay Two Stray terhadap hasil belajar siswa pada mata pelajaran ekonomi di SMA Muhammadiyah 1 Palembang. Hal ini terlihat dari hasil hipotesis yang diperoleh $t_{\text {hitung }}>t_{\text {tabel }}$ atau 8,949>1,994 berarti tolak Ho dan terima $\mathrm{Ha}$ maka ada pengaruh yang signifikan model pembelajaran two stay two stray terhadap hasil belajar.

2. Berdasarkan hasil yang dilakukan menggunakan rumus koefisien determinasi $\left(r^{2}\right)$ maka besar pengaruh model pembelajaran two stay two stray terhadap hasil belajar siswa yaitu $79,48 \%$ sedangkan sisanya sebesar $20,52 \%$ di pengaruhi faktor lain.

\section{DAFTAR PUSTAKA}

Arikunto Suharsimi .Edisi 2. 2017. Dasar-Dasar Evaluasai Pendidikan. Jakarta: Bumi Aksara.

Alhikmah Luluk.(2016)."Penerapan Pembelajaran Kooperatif Tipe Two Stay Two Stray Untuk Meningkatkan Aktivitas Dan Motivasi Belajar Siswa Kelas $\mathrm{X}$ Akuntansi 2 SMK Muhamdiyah 1 Yogyakarta.Tahun Ajaran 2015/2016.Yogyakarta:Univers itas Negeri Yogyakarta.

Huda Miftahul. 2013. Model-Model Pengajaran dan Pembelajaran. Yogyakarta: Pustaka Pelajar Offset.

Ismawati.N.(2011).’Penerapan Model Pembelajaran Kooperatif Dengan Pendekatan Struktural Two Stay Two Stray Untuk Meningkatkan Hasil Belajar Siswa Kelas X SMA N 1 Boja".Jurnal Pendidikan Fisika Indonesia.OnlineVol.1No.2Hal .38-41.ISSN:1693-1246.

http//www.journal.unnes.ac.id./.diaks es tanggal 13 April 2019 
Jihad Asep, Haris Abdul. 2013. Evaluasi Pembelajaran. Yogyakarta: Multi Pressindo.

Kosasih, E. (2014).Strategi Belajar dan Pembelajaran.Bandung: Yrama Widya

Kusumaningrum Ratih.(2015). "Eksperimentasi Model Pembelajaran Tipe Two Stay Two Stray (TSTS) Numbered Heads Together (NHT),Dan Think Pair Share (TPS) Pada Materi Lingkaran Ditinjau Dari Kreaktifitas Belajar Matematika Siswa SMP Negeri DI Kabupaten Sukoharjo".Jurnal Elektronik Pembelajara Matematika.Vol 3 No.7 Hal 705-716 .ISSN:2339-1685.

http:// Jurnal .Fkip .uns.ac.id/.diakses pada tanggal 27 April 2019.

Lubis Adlan Muhammad.(2018). "Pengaruh Model Pembelajaran Kooperatif Tipe Two Stay Two Stray (TSTS) Dan Artikulasi Terhadap Hasil Belajar Siswa Pada Materi Ekosistem Di SMA Negeri 1 Sibabangun Kabupaten Kapaluli Tengah “. Jurnal Biolokus.Vol 1 N O 2 Hal 117122.ISSN :2621 - 3702.http:// Jurnal Biolokus .ac.id/.diakses pada tanggal 14 Mei 2019.

Ngalimun .2017.Strategi Pembelajaran .Jogyakarta :Dua Sastria Offet

Rusman.2012. Belajar dan Pembelajaran Berbasis Komputer Mengembangkan Profesionalisme Guru Abad 21. Bandung: ALFABETA.

Rosdiandi.2012.Model Pembelajaran Langsung dalam pendidikan jasmani dan kesehatan.Bandung : Alfabeta Sugiyono.2015. Metode Penelitian Pendidikan Kualitatif dan Kuantitatif.

Suprijono.2009.Cooperative Learning.Surabaya : Pustaka Belajar

Susanto Ahmad.2013.Teori Belajar Pembelajran di sekolah dasar .Jakarta :Prenandamedia Grup Syaiful Bahri Djamarah .2010.Strategi Belajar Mengajar .Jakarta :Rineka Pelajar.

Shoimin .2017. Model Pembelajaran inovatif dalam kurikulum 2013.Jakarta :Ar - Ruzz Media

Syamsiah Siti."Penerapan Model Pembelajaran Kooperatif Tipe Two Stay Two Stray Pada Mata Pelajaran IPS Untuk Meningkatkan Hasil Belajar Siswa Kelas 1V A SD N Simulyo 8 Surabaya".Jurnal PGSD.Online Vol.02 No 01 hhtp://www.jurmal uns.ac.id/ diakses pada tanggal 27 April 2019. 